\section{Endoscopic needle-knife treatment of refractory ileo-ascending anastomotic stricture}

A 45-year-old man with Crohn's disease diagnosed in 1988 who had undergone an ileocecal resection with an end-to-side anastomosis in 1995 presented with pain in the right lower abdomen. A colonoscopy was performed using an Olympus colonoscope (Tokyo, Japan), during which a noninflamed fibrotic stricture of the anastomosis that could not be passed by the endoscope was found ( Fig. 1 ). Because the patient refused surgery, six balloon dilations of the stricture were performed at 3-monthly intervals. Unfortunately these resulted in limited improvement in both the degree of stenosis and the patient's symptoms.

In order to overcome the stricture, it was decided to incise the fibrotic bridge with a needle-knife papillotome (Zimmon needle-knife papillotome; Cook Medical
Europe, Limerick, Ireland; Fig. 2). It was possible to make this incision safely because of a perfect view of the tissue loop in a parallel position. After the incision had been made, the endoscope was able to be passed beyond the anastomosis. Normal ileal mucosa was seen immediately beyond the anastomosis. At follow-up colonoscopy 3 months later, it was still possible to pass the endoscope beyond the anastomosis. During 7 months of follow-up, the patient has remained symptom free.

Fibrotic strictures of the ileo-ascending anastomosis are common complications of Crohn's disease after ileocecal resection [1]. Drug treatment is ineffective in the absence of active inflammation. To minimize the need for multiple resections, bridge, the enteral loop, and the colonic

bowel-conserving strategies that include surgical stricturoplasty and endoscopic balloon dilation have been developed. The long-term success rate of endoscopic dilations is high (80\%) [2].

Only a few case series of endoscopic needle-knife incision have been published. These include needle-knife incision of upper gastrointestinal anastomotic strictures [3], anastomotic sinuses [4], and rectal anastomotic strictures [5]. To our knowledge, we present the first case of a successful needle-knife incision of an ileo-ascending anastomotic stricture in a patient with Crohn's disease. Balloon dilation can sometimes be ineffective, especially in very rigid fibrotic strictures, and in these cases needle-knife incision might provide an alternative treatment to balloon dilation.

Endoscopy_UCTN_Code_TTT_1AQ_2AF

\section{Competing interests: None}
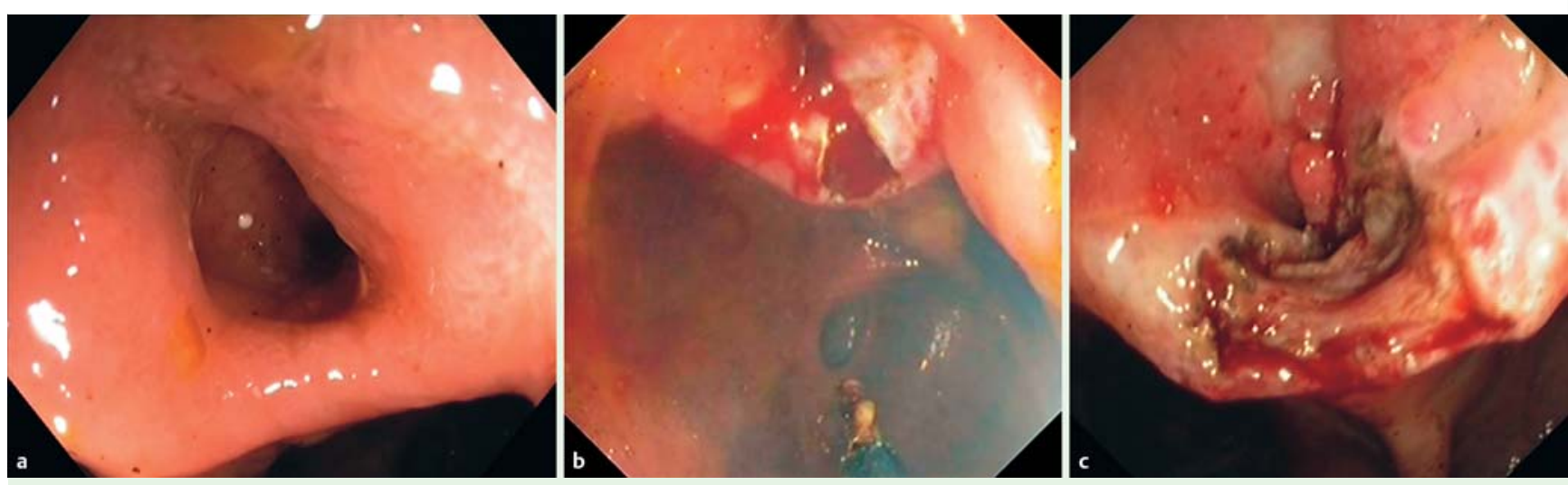

Fig. 2 Colonoscopic appearance showing the ileo-ascending anastomotic stricture: a before needle-knife incision; $\mathbf{b}$ during needle-knife incision; $\mathbf{c}$ after needle-knife incision. 


\section{Kerkhof, P. Dewint, A. D. Koch, C. J. van der Woude}

Department of Gastroenterology and Hepatology, Erasmus MC University Medical Center, Rotterdam, The Netherlands

\section{References}

1 Rutgeerts P, Geboes K, Vantrappen G et al. Predictability of the postoperative course of Crohn's disease. Gastroenterology 1990; 99: 956-963

2 van Assche G, Thienpont C, D'Hoore A et al. Long-term outcome of endoscopic dilatation in patients with Crohn's disease is not affected by disease activity or medical therapy. Gut 2010; 59: 320 - 324

3 Hordijk ML, Siersema PD, Tilanus HW et al. Electrocautery therapy for refractory anastomotic strictures of the esophagus. Gastrointest Endosc 2006; 63: 157-163

4 Lian L, Geisler D, Shen B. Endoscopic needle knife treatment of chronic presacral sinus at the anastomosis at an ileal pouch-anal anastomosis. Endoscopy 2010; 42: 14

5 Truong S, Willis S, Schumpelick V. Endoscopic therapy of benign anastomotic strictures of the colorectum by electroincision and balloon dilatation. Endoscopy 1997; 29: 845 849
Bibliography

Dol http://dx.doi.org/

10.1055/s-0032-1325973

Endoscopy 2013; 45: E57-E58

(c) Georg Thieme Verlag KG

Stuttgart · New York

ISSN 0013-726X

\section{Corresponding author}

\section{J. van der Woude, MD PhD}

Erasmus MC University Medical Center

Department of Gastroenterology and Hepatology

Postbus 2040

3000 CA Rotterdam

The Netherlands

Fax: +31-10-4632793

c.vanderwoude@erasmusmc.nl 